report on what they have been doing at least once a year. Apart from the benefits that would follow for DNA researchers, questions of industrial secrecy would also by such a step be simplified enormously. In moving towards such a system, however, the committees should be much more concerned than in the past to coordinate their practice internationally. The unfortunate case of Dr Samuel Kennedy of the University of California (see Nature 18 September) may be a vivid illustration of the trouble caused when governments follow different standards. Nobody can know at this stage what part international competition played in the affair, but the German guidelines were at the time less stringent than the American - and Dr Kennedy's chief rivals in the study of the arbovirus genome are in West Germany. Is it not high time that the regulatory committees recognized that such ironies will persist as long as they decline (as they have almost studiously done) to talk to each other directly?

The question remains of how best to deal with problems like those occasioned by genetic manipulation which are certain to arise again. In retrospect, in countries as different as Britain and the United States, the committees set up to hold the ring between the public and the molecular biologists have served reasonably well. If anything, the molecular biologists have been more frustrated than the public, which is only right and proper. On balance, especially in the early days, it would have been helpful if the proceedings of the British group responsible for the guidelines had been carried on in public as, for most of its time, the corresponding American committee has been required to do by the Freedom of Information Act. Many incipient misunder- standings about the functioning of the Genetic Manipulation Advisory Group have been consequences of the secrecy imposed on it under the Official Secrets Act as well as by the conventions of Whitehall. People may rightly ask what kind of public assurance can stem from the proceedings of a secret committee. Even so, the committee has functioned better than many expected.

The most obvious deficiency of the past few years is that, faced with a problem of assessing the safety of a new and unexplored laboratory technique, the responsible committees (and the scientific community itself) did very little to provide the data on which objective assessments of safety might be based. It is true that people have fed each other quantities of $E$. coli from time to time, and there have been a few half-hearted attempts to see whether genes incorporated into bacteria can find their way into the somatics cells of laboratory animals. Few opportunities have been seized for looking into the ways in which bacteria carrying foreign genes might actually damage their adventitious hosts. The customary explanation, during most of the past five years, is that the people most competent to carry out such experiments have been too preoccupied with exploiting the new techniques whose safety was called in question. With a few conspicuous (and honourable) exceptions, those with the most vivid interest in demonstrating that their techniques are as safe as they now appear have been content with arm-waving. They, as well as the rest of us, are lucky that things have turned out as they have, and that the general perception of the risks of genetic manipulation has so quickly, and painlessly, moderated. It could have turned out quite differently.

\title{
McNamara's fond farewell to his bank
}

Who would think that the president of a large automobile manufacturer turned US Secretary of Defense at the height of the Vietnam War would turn out to be a superb president of the World Bank? The credentials, impressive enough, are on the face of things unfitting. Yet the governors of the bank plainly knew what they were doing when they appointed Mr Robert McNamara to his present post nearly fourteen years ago. During that period he has managed both to dramatize the cause of economic development in the poorest countries of the world and then to make the World Bank itself into a powerful instrument for prosecuting that cause. He has, in other words, justly earned the right to make the fierce complaints which marked his valedictory address to the members of the bank last week. And he is right, of course, to note that the cause of development has gone sour in the past few years, right to complain that many industrialized countries (Britain was singled out) are reducing their contributions to overseas aid, right to complain that the OPEC surplus states should carry a much greater burden and right to fear for those who carry the true burden of development:

"We do not see their faces, we do not know their names, we cannot count their number. But they are there. And their lives have been touched by us, and ours by them."

In retrospect, $\mathrm{Mr}$ McNamara's most cheerful memories will no doubt be of the early 1970s, when he was stumping the world urging governments that they should not forget the "poorest of the poor" and at the same time persuading the members of his bank that their funds should be invested as often in social infrastructure as in mammoth capital projects. Even then, however, it was an uphill struggle. With a few rare exceptions (Sweden, for example), most industrialized countries never consistently came near the United Nations target for overseas aid of 0.7 per cent of GNP. Since the increase of the price of oil, performance has worsened - and the World Bank has become even more important as a source of multilateral aid. The explanation is, unfortunately, all too simple. Industrialized governments have become obsessed with domestic problems, many of them caused by the increased price of oil. But at a time when voters are being asked to pay more tax or to do without public services, governments are plainly unwilling to prosecute the cause of development. The Brandt Commission was upbraiding them for their neglect earlier in the year. $\mathrm{Mr}$ McNamara has now added his complaints.

The complaints are fair, but they will not be listened to with much care. One trouble is that governments are preoccupied with other things. A more serious difficulty, which both the Brandt Commission and Mr McNamara overlook, is that the cause of development has gone sour because relations between the industrialized states and the rest of the world have themselves gone sour. Although most oil consumers recognize by now that the crude oil prices of the 1950s and 1960s were unfair to the oil producers, they have not enjoyed the humiliations of the past few years, or the economic upheavals that have gone with them. And they will not forget them. In such circumstances however, it is natural enough, if wrong, that the Western oil consumers should be saying that if any group of states should take responsibility for helping with economic development of the poor countries, the OPEC states are the obvious candidates. So (as Mr McNamara says) they are. Unfortunately the OPEC states are even more preoccupied with their own problems than are the industrialized states of the West. Since there is no prospect that the members of the Warsaw Pact and its adherents will produce the kind of help that the developing countries need, it is no wonder that $\mathrm{Mr}$ McNamara's speech was so gloomy.

So is all hope lost? Not quite. Or perhaps not yet. There are a few clouds with silver linings. The OPEC states have somehow to manage their surpluses, usually by asking other people to do that on their behalf. There may be some pickings for development there. Better, even the past two sad decades have shown that some developing countries can actually develop, and make good. The example of India is not a joke. Better still, it appears now to have been understood in the West (but also in the developing world) that development assistance is not the provision of capital funds but help with the process of development, "infrastructure" as the saying goes. Sometimes this means teaching businessmen how to do accounts, politicians how to be ministers and children how to read. Building roads is by these standards capital-intensive. If only Mr McNamara had had another fourteen years, he might have been able to demonstrate what many suspect - that the most imaginative development is cheap. 